Jurnal Teknik Komputer AMIK BSI

Volume 7, No.1, Januari 2021

P-ISSN 2442-2436, E-ISSN: 2550-0120

Akreditasi Ristekdikti, No: 36/E/KPT/2019 (Sinta 4)

DOI: $10.31294 /$ jtk.v4i2

\title{
FinTech and Bank: Past, Present, and Future
}

\author{
Mercurius Broto Legowo ${ }^{1}$, Steph Subanidja², Fangky Antoneus Sorongan ${ }^{3}$ \\ ${ }^{1}$ Faculty of Information Technology, Perbanas Institute, Jakarta \\ ${ }^{2}$ Post Graduate School of Management, Perbanas Institute, Jakarta \\ ${ }^{3}$ Faculty of Economics and Business, Perbanas Institute, Jakarta \\ 1e-mail: mercurius@perbanas.id \\ 2e-mail: steph@perbanas.id \\ 3e-mail: f.sorongan@perbanas.id
}

\begin{tabular}{ccc}
\hline Received & Revised & Accepted \\
$21-12-2020$ & $23-12-2020$ & $25-01-2021$ \\
\hline
\end{tabular}

\begin{abstract}
Abstrak - Teknologi Keuangan telah lama diterapkan pada sektor keuangan dan perbankan hingga munculnya inovasi teknologi keuangan yang disebut FinTech. Merujuk pada evolusi FinTech hingga saat ini, FinTech memengaruhi aktivitas Bank dari masa lalu, sekarang, dan masa depan. Berdasarkan fakta tersebut, penelitian ini bertujuan untuk menyajikan analisis deskriptif FinTech dan Bank di masa lalu, sekarang, dan masa depan, khususnya di Indonesia sebagai studi kasus. Penelitian ini menggunakan metode penelitian analisis deskriptif dan menggunakan pendekatan metode kualitatif. Analisis deskriptif ini dilakukan dengan mengkaji secara kritis berbagai jurnal ilmiah yang relevan, fakta-fakta fenomena FinTech di Indonesia, dan makalah dokumentasi dari lembaga perbankan. Hasil analisis ini mengungkapkan apa yang terjadi pada FinTech dan Bank Dunia di masa lalu, sekarang, dan masa depan. Kontribusi dari studi ini dapat memberikan wawasan dan pemahaman terkait FinTech dan perbankan di masa lalu, sekarang, dan masa depan secara lebih mendalam.
\end{abstract}

Kata Kunci: Bank, FinTech, Past-Present-Future

\begin{abstract}
Financial Technology has long been applied to the financial and banking sectors until the emergence of financial technology innovation called FinTech. Referring to the evolution of FinTech until now, FinTech influences the Bank's activities from the past, present, and future. Based on these facts, this research aims to present a descriptive analysis of FinTech and Bank in the past, present, and future, especially in Indonesia as a case study. This study uses a descriptive analysis research method and using qualitative method approaches. This descriptive analysis is carried out by critically reviewing various relevant scientific journals, the facts of the FinTech phenomenon in Indonesia, and documentation papers from banking institutions. The results of this analysis reveal what happened to FinTech and the Bank in the past, present, and future. The contributions from this study can provide insight and understanding related to FinTech and banks in the past, present, and future more in-depth.
\end{abstract}

Keywords: Banks, FinTech, Past-Present-Future

\section{INTRODUCTION}

FinTech is increasingly becoming a global trend created by innovators and closely followed by academics, and is now attracting the attention of FinTech regulators in the past, present, and future in the financial and banking industries(Mention, 2019). Nowadays, FinTech is an industry that uses Information Technology centered on cellphones/smartphones to improve financial system efficiency. Meanwhile, technology is related to the Internet, for example, Cloud Computing or mobile Internet will encourage established financial services industry businesses, such as Lending money or banking transactions(Gomber et al., 2017). In Indonesia, FinTech usually refers to a mobile payment (m-payment) product. All major ecommerce sites or online shopping systems have built-in their company a specific payment version of this Fintech product (Teja, 2017). The CBNC Indonesia survey revealed that FinTech payment products owned $39 \%$ of all FinTech products in Indonesia (CNBC Indonesia, 2017). Startups, as FinTech services organization in Indonesia, is developing very rapidly. The latest data in 2019 from StartupRanking, Indonesia is ranked fifth from the list of countries in the world that have the most number of technology-based startups, with a total of 2182 startups(Startupranking, 2019). Besides, there has been an evolution of FinTech as technology 
innovation in the banking sectors(Prawirasasra, 2018; Thakor, 2019).

Indeed, the application of this IT innovation to banks through FinTech digital platforms can provide financial services to the public at a lower cost than traditional banking(Jakšič \& Marinč, 2019). Business drivers influence the adoption of infrastructure technology(FinTech) in the financial and banking services industry(Rabhi, 2016). FinTech mechanism influencing technological innovation for banking and financial services (Gomber et al.,2018). Meanwhile, organizations as business drivers can create innovation(Baporikar, 2018). One perception that arises is that this industry will threaten the existence of conventional financial institutions, such as banks. This perception arises because of concerns that the bank was disrupted by FinTech. Many opinions from practitioners and researchers said that FinTech is a disruption in financial services (Prawirasasra, 2018; Dermine, 2017). The Indonesian government made various banking regulations through the financial services authority to respond to the existence of FinTech in the banking system (Mutiara et al., 2019). In the past beginning in the 1990s, banks in Indonesia began to use many ATMs as financial technology innovations in transactions. The Indonesian Central Bank of Indonesia (BI, abbreviated in Indonesia) and the Indonesian Financial Services Authority (OJK, in Indonesia) are currently anticipating the negative effect of FinTech's growth in the financial and banking sector in the form of policies, legislation, and regulations. Bank Indonesia as a Central Bank has developed a blueprint that aims to navigate Indonesia's Payment System (IPS) in the Digital Age (Bank Indonesia, 2019). Hence, the Indonesia Financial Services Authority made the targets in its master plan, how FinTech collaborates with the financial and banking industry (OJK, 2017). This disruption or collaboration of the Fintech industry has become a concern and considered by the banking services industry in Indonesia. Thus, many things will be considered related to the impact of FinTech on banks in Indonesia for the future.

There are many previous research related FinTech and Banks which support this study. Anne-Laure Mention(Mention, 2019), in a related study on FinTech's future, FinTech clarified the synergistic and concentrated efforts required from banks, Fintech practitioners and financial service regulators to grow the future of FinTech and move towards successful action. A study from Jakšič \& Marinč[8], related the future of Banking, revealed that the drastic change are also expected in the banking sector due to the rise of FinTech startups and IT companies in traditional banking businesses. Stulz stated in 2019(Stulz, 2019) that in the future, the presence of Fintech and BigTech contributes to traditional banks' propensity to lose their competitive and strategic edge because they lack access to unique credit-seeking party information. Studies relating to the growth of FinTech in the Indonesian banking systems has been carried out by Mutiara et al.,(Mutiara et al., 2019). In this study, it concluded that now and for the future, banking and fintech can continue to run optimally and not only see each other as competitors but also business partners, so there need to be integrated regulations between the two regulators and policymakers. Legowo et al.(2020) study elaborated based on FinTech conceptual model, which has the constructs is business drivers, Fintech mechanisms, and technological innovation. The results of this study indicate FinTech, as an IT application for finance according to its a mechanism will create various technological innovations in the financial business sector, including a bank.

This study examines the relationship between FinTech and the Bank in the past, present, and future, in Indonesia. And specifically, this study refers to the concept of FinTech evolution(Prawirasasra, 2018; Thakor, 2019) which has been the subject of previous research studies.

\section{LITERATURE REVIEW}

As far as we all know, it said that Technology or later Information Technology is the main driving force of business in various business sectors, especially in Banks.

\section{FinTech}

In curent years, digitization in the banking sector reflects the rise of FinTech, which represents a relationship or a combination of Finance and Information Technology(Prawirasasra, 2018; Minerva, 2016; Kim et al., 2016). According to Zavolokina et al., (2016) stated that the mechanism of a FinTech is indicated by the way to create/change/improve a business model. Furthermore, FinTech has a mechanism for disruption or collaboration (Prawirasasra, 2018). Finally, a real indication of Fintech is the application of IT to Finance(Wulan, 2017).

IOSCO, which is an international organization board for securities commission, has stated that the term FinTech used to describe various business models and new technological innovations that have the potential to change the financial services industry(IOSCO, 2017). Also, World Economic Forums added that Fintech, as new entrants have the potential for transformation and innovation in the business model of financial services (WEF, 2015). However, in this research, based on preferences related to FinTech at the Bank, it states that FinTech 
defines a new technological innovation that aims to improve the Bank's automation of financial services.

Indeed, related to its development, there has been an evolution of FinTech in the financial and banking industries(Prawirasasra, 2018: Thakor, 2019). The evolution of FinTech shown in Fig. 1.

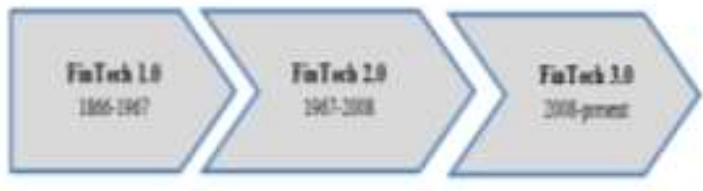

Source : Thakor(2019))

Figure 1. Phases in FinTech Evolution

FinTech 1.0, (1866-1967), where the transition from Analog to Digital took place in this era. FinTech 2.0, (1967-2008), where the development of Digital Financial Services at Traditional Banks started within this era. FinTech 3.0 (2008-present) is what referred to as the Democratization of Electronic Financial Services. However, the Financial Services Authority(OJK, 2017) in Indonesia mentions FinTech 3.0-3.5, (now until the future) in this era, many startups tend to deliver a range of alternative traditional banking services, and Internet-based financial services operated by outsiders.

Frame et al. (Frame et al., 2018) mentioned types of FinTech innovations, believed to change the future of the financial and banking industry,namely: (1) Blockchain or Distributed Ledgers is a modern development system that has the potential to bring about a banking revolution with related technologies. Blockchains are an example of a distributed ledger that has data that shared at all points or nodes in the network. Recently, this distributed ledger technology seems to have the potential to disrupt further payment services via cryptocurrency. (2) Artificial Intelligence and Machine Learning are other significant emerging technologies that have significantly affected and applied banking in recent years(Frame et al., 2018).

\section{Banks}

Banks are institutions that have significant roles to play in a country's economy. Banks are financial institutions that are operated by the government or the private sector and deal with financial debt and credit problems.. It lends, accepts, and deposits money builds the gap between the lenders and the borrowers(Prabhavathi \& Dinesh, 2018). In general, the provision of deposit and loan products distinguish banks from other types of financial firms. According to Trębacz (2019) the name "bank" is also associated with medieval transactions, and it assumed that the term "bank" comes from the Italian word "banco" and means bench, counter, where money traders have carried out banking operations.
According to the Law of the Republic of Indonesia, number 10 the year 1998 in article, paragraph 2 related Banks definition in a study from Mutiara et al. (Mutiara et al., 2019) defined that a bank is a financial business institution that collects funds from the community in the form of deposits and distributes them to the community in the form of credit and others form that aims to improve life many people. From this understanding, it concluded that the banking business includes three activities, namely fundraising activities, fund distribution activities, and the provision of other banking services. Banks in the past often referred to as Traditional Banks. However, at present, many banks are referred to as Virtual Banking, Digital Banking, or Modern Banking. In the future, the condition of banking operations predicted to be different from now, so this usually referred to as Future Banking.

\section{METHODOLOGY}

The research methodology used in this study is a descriptive analysis research method with a qualitative approach. According to Loeb et al., (2017) mentioned that descriptive analysis is relevant to all types of research. It can stand alone as a complete research project or supplement causal analysis. This descriptive analysis carried out by collecting data from various relevant scientific journals, facts of the FinTech phenomenon in Indonesia, and documentation papers from banking institutions. In analyzing data, a descriptive approach used from the secondary data collected. The analysis refers to the evolution of FinTech, which influences the Bank's activities from the past, present, and future.

\section{RESULTS AND DISCUSSION}

\section{Results}

In the beginning, the results of this study provide an overview of the scope of this study. Referring to the FinTech evolution, then FinTech and the Bank in the past, present, and future, are illustrated as Figure 2.

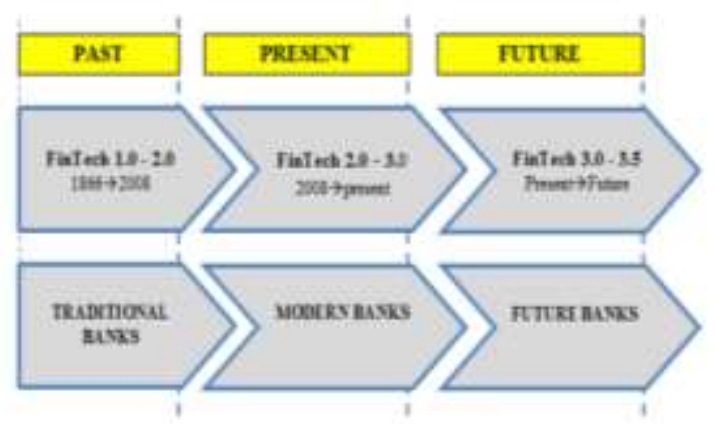

Source : Own research (2020)

Figure 2. FinTech and Bank: Past, Present, and Future

\subsection{FinTech and Banks in Past}


FinTech in Past (FinTech $1.0-2.0$ ) : In brief, in this past for the development of FinTech closely related to the development of enabling technologies. In this era, the community began to be introduced ATMs that became a transition from analog to a digital industry(Prawirasasra, 2018). In this past, technology has a role in delivering information across borders, including information in financial(Thakor, 2019). The merchant should order products by telephone and travel his wealth around the globe without any effort or difficulty. Besides Thakor(Thakor, 2019) stated Installation of the first trans-Atlantic cable and use of the Telegraph and fast transmission of transactions and payment of financial information.

Banks in the Past : In the past, the function of banks in providing savings and loan service products, which usually distinguishes banks from other types of financial companies, is what referred to as traditional banks(Mishra, 2012). Besides, Mishra (2012) referred to technical advances in banks in this era as described in the following:(1960)-Mechanical banking introduced, (1970)-Computer-based banking industry introduced, (1980)-Release of computer-based banking communication.

\subsection{FinTech and Banks in Present}

FinTech in Present (FinTech 2.0 - 3.0): In the present, in the transition from the FinTech 2.0 era to the FinTech 3.0 era (Leong, 2018). At this era of evolution, Automatic Teller Machine (ATM) is one of the technological innovations taking place in the world financial sector(Prawirasasra, 2018). The ATM is the most important financial innovation. Thus, this era is a transition from analog to the digital industry. E-Payment, clearing systems to improve products and services in the traditional financial banks(Thakor, 2019).

Bank in the Present: In present, Commercial bank is undergoing a rapid change towards virtual banking. A Virtual banks defined as non-branch banks, as providers of banking services through electronic media used, like ATMs, telephones, personal computers, the internet(Mishra, 2012). Besides, at present many people call the existence of Modern Bank covers many aspects in the application of technology such as mobile banking, online banking, and ATM(Hamzaee \& Hughs, 2011). Also, the presence of mobile banking and the use of mobile devices will send messages and financial information, as well as consumer transactions, such as checking account balances, accessing other banking services, and goods that transfer funds from anywhere at any time.

\subsection{FinTech and Banks in Future}

FinTech in Future (FinTech 3.0 - 3.5): The 2008 global financial crisis took place and impacted the banking and finance industries(Prawirasasra, 2018).
In this era, it can be called the emergence of the Democratization of Digital Financial Services(Prawirasasra, 2018). The use of technical advances by these entrants will provide financial services to customers without direct intermediaries. (Thakor, 2019). In the FinTech 3.0 era, the latest technology is growing like the Internet and the Internet of Things (IoT), whereas, towards the FinTech 3.5 era, more and more Data Analytics technology will develop in the banking industry. The collaboration mechanism is one of how to keep FinTech developing in the future in the banking industry. Without a collaboration mechanism, almost 95 percent of fintech companies will fail in the upgrade phase. FinTech companies will always compete with banks for certain activities. Future FinTech products related to banking include: Bitcoin, Blockchain is a distributed ledger, Cryptocurrency, and Robo advisors(Frame et al., 2018).

Banks in the Future: In the future, in the banking business, furthermore, there will be FinTech Bank and BigTech firm(Stulz, 2019). FinTech Bank is a fintech firm that conducts business activities, such as online banking. FinTech Bank is also a FinTech company that synergizes and collaborates with traditional banks. FinTech Bank can compete with traditional banks on user interface applications with a variety of transaction products with financial access widely. Note that Big Tech Firm is a technology firm with a business model focused on the use of digital technologies(Stulz, 2019). Amazon is an example of this in the US, and Alibaba is BigTech in China. BigTech Company's unique advantages allow them to replace traditional bank activities. BigTech's real strength exists in banking, particularly when it comes to consumer financing and lending to SMEs banks.

\section{Results}

The existence of FinTech and the Bank in the past, present, and future influenced by business drivers, FinTech mechanics, and technological innovation developed. The statement is following the Fintech conceptual model developed in previous research(Legowo et al., 2020).

The development of FinTech and Banks in Indonesia began with the use of ATMs in the past(Prawirasasra, 2018). Besides, at present, the rapid growth of Startup(Startupranking, 2019) is expected to have an impact on banks, especially in payment transactions(CNBC Indonesia, 2017). Bank Indonesia, as the policymaker and OJK as the financial services regulator, has anticipated the development of FinTech for the future(Bank Indonesia, 2019; OJK, 2017). Meanwhile, FinTech Bank and BigTech in Indonesia are still a discourse and predicted to be the bank of the future(Stulz, 
2019). The previous studies(Mention, 2019; Jakšič \& Marinč, 2019; Stulz, 2019; Mutiara et al., 2019; Legowo et al., 2020) related to FinTech and Bank reviewed all support this study. This study provides practical implications for the banking industry in how to create technology innovations through FinTech in their business for the future.

\section{CONCLUSION}

In summary, this research purpose of presenting a descriptive analysis related to FinTech and Bank in the past, present, and future, especially in Indonesia as a case study.

Till the present, the use of ATMs in traditional banks in Indonesia is a form of implementation of FinTech. In the present, the collaborating of the Modern Bank and FinTech Industry expected to increase financial inclusion in banking. Need to be a consideration for the Future Bank in-depth related to the presence of FinTech and BigTech companies in the future. For future ideas, research needed to examine in depth the influence of FinTech in Banks and Banking Systems in Indonesia.

\section{ACKNOWLEGMENT}

Thanks to the Research and Technology Ministry/the National Innovation Research AgencyThe Republic of Indonesia (KEMENRISTEK/BRIN-RI) grants support for multi-year work under the 'Fundamental Research' scheme in 2020.

Thanks to The Committee of International Conference on Advanced Information Scientific Development (ICAISD-2020) for providing the opportunity to present this paper at this conference on August 6-7, 2020, and awarding it as Best Presenter.

\section{REFERENCES}

Bank Indonesia. (2019). Indonesia Payment Systems Blueprint 2025 Bank Indonesia: Navigating the National Payment Systems in the Digital Era. Retrieved from https://www.bi.go.id/.../Indonesia-PaymentSystems-Blueprint-2025- Presentation.pdf

Baporikar, N. (2018). Drivers of Innovation. In Chapter 14 (pp. 250-268). http://doi.org/10.4018/978-1-4666-64579.ch014

CNBC Indonesia. (2017). FinTech Business in Indonesia. In CNBC Indonesia Surveys. Retrieved from https://www.cnbcindonesia.com/tech/2018011 0145800-37-1126/
Dermine, J. (2017). Digital Disruption and Bank Lending. European Economy - Banks, Regulation, and the Real Sector, 3(2), 63-76. Retrieved from www.european-economy.eu

Frame, W. S., Wall, L., \& White, L. J. (2018). Technological Change and Financial Innovation in Banking: Some Implications for FinTech. ( and J. O. S. W. Allen Berger, Phillip Molyneux, Ed.) (3 rd Editi). New York, USA.

Gomber, P., Koch, J.-A., \& Siering, M. (2017). Digital Finance And FinTech: Current Research And Future Research Directions. Journal of Business Economics, 87(5), 537580. http://doi.org/10.1007/s11573-017-0852-X

Gomber, P., Parker, C., Kauffman, R. ., \& Weber, B. (2018). On the Fintech Revolution: Interpreting the Forces of Innovation , Disruption, and Transformation in Financial Services On the Fintech Revolution : Interpreting the Forces of Innovation , Disruption and Transformation in Financial Services. Journal of Management Information System, 1(January), 1-14. http://doi.org/10.1080/0742122.2018.1440766

Hamzaee, R. G., \& Hughs, B. (2011). Modern Banking And Strategic Portfolio Management. Journal of Business \& Economics Research (JBER), 4(11), 85-95. http://doi.org/10.19030/jber.v4i11.2718

IOSCO. (2017). IOSCO Research Report on Financial Technologies (Fintech). International Organization of Securities Commissions. $\quad$ Retrieved from https://www.iosco.org/library/pubdocs/pdf/IO SCOPD554.pdf

Jakšič, M., \& Marinč, M. (2019). The Future of Banking: The Role of Information Technology. International Journal of Scientific and Technology Research, 8(6), 305-308. http://doi.org/10.1016/b978012437160-6/50009-4

Kim, Y., Ju Park, Y., Choi, J., \& Yeon, J. (2016). The Adoption of Mobile Payment Services for “ Fintech ." International Journal of Applied Engineering Research., 11(2), 1058-1061.

Legowo, M. B., Subanija, S., \& Sorongan, F. A. (2020). Role of FinTech Mechanism to Technological Innovation: A Conceptual Framework. International Journal of Innovative Science and Research Technology, $5(5), 1-6$.

Leong, K. (2018). FinTech (Financial Technology): What is It and How to Use Technologies to Create Business Value in Fintech Way? International Journal of Innovation, Management and Technology, 9(2), 74-78. http://doi.org/10.18178/ijimt.2018.9.2.791

Loeb, S., Dynarski, S., McFarland, D., Morris, P., 
Reardon, S., \& Reber, S. (2017). Descriptive Analysis in Education: A Guide for Researchers. U.S. Department of Education, Institute of Education Sciences. National Center for Education Evaluation and Regional Assistance. Institute of Education Science. http://doi.org/10.1094/PDIS.2003.87.5.550

Mention, A. L. (2019). The Future of Fintech. Research Technology Management, 62(4), 5963.

http://doi.org/10.1080/08956308.2019.163123

Minerva, R. (2016). The Potential Of The FinTech Industry To Support The Growth Of SMEs In Indonesia. MBA Degree Thesis.

Mishra, D. S. K. (2012). Virtual Banking: From Conventional to Competitive Approach. SSRN Electronic Journal, (August 2009). http://doi.org/10.2139/ssrn.1842923

Mutiara, U., Candanni, L. R., \& Hasibuan, R. R. (2019). Construction of Financial Technology in Banking Systems in Indonesia. Jurnal Hukum NOVELTY, 10(02), 150-163.

OJK. (2017). Financial Technology (FinTech) in Indonesia. Paper FinTech-IBS. http://doi.org/http://dx.doi.org/10.1016/j.jmir.2 014.03 .053

Prabhavathi, K., \& Dinesh, G. P. (2018). Banking: Definition and Evolution. International Journal of Scientific \& Engineering Research, 9(8), 745-753.

Prawirasasra, K. P. (2018). Financial Technology in Indonesia: Disruptive or Collaborative? Reports on Economics and Finance, 4(2), 8390.

Rabhi, F. A. (2016). Building the Business Case for SOA: A Study of the Business Drivers for Technology Infrastructure Supporting Financial Service Institutions. In International Workshop on Enterprise Applications and Services in the Finance Industry. Springer, Berlin, Heidelberg. http://doi.org/10.1007/9783-642-01197-9

Startupranking. (2019). Startup Ranking Countries. Retrieved from https://www.startupranking.com/countries

Stulz, R. M. (2019). FinTech, BigTech, and the Future of Banks. Journal of Applied Corporate Finance, 31(4), 86-97. http://doi.org/10.1111/jacf.12378

Teja, A. (2017). Indonesian Fintech Business : New Innovations or Foster and Collaborate in Business Ecosystems? Literature Study and Hypothesis Development. The Asian Journal of Technology Management, 10(1), 10-18.

Thakor, A. V. (2019). Fintech and Banking: What do we know? Journal of Financial Intermediation, $\quad$ (January), 1-13. http://doi.org/10.1016/j.jfi.2019.100833

Trębacz, T. (2019). FinTech as an innovative banking sector, 122(February), 83-95.
WEF. (2015). World Economic Forum-The Future of Financial Services. World Economic Forum. http://doi.org/10.1002/9781119218906.ch59

Wulan, V. R. (2017). Financial Technology ( FinTech ) A New Transsaction In Future. Journal of Electrical Engineering and Computer Sciences, 2(1), 177-182.

Zavolokina, L., Dolata, M., \& Schwabe, G. (2016). FinTech - What's in a Name? Thirty Seventh International Conference on Information Systems Proceeding, 1-19. 